\title{
Multiple Autoimmune Syndrome pada Pasien Erupsi Obat Alergi akibat Obat Antituberkulosis dengan Hyper IgE
}

\author{
Fandi Triansyah ${ }^{1}$, Raveinal $^{2}$
}

\begin{abstract}
Abstrak
Multiple Autoimmune Syndrome (MAS) merupakan koeksistensi dari tiga atau lebih penyakit autoimun. Kejadian MAS ini cenderung tinggi pada pasien dengan riwayat penyakit autoimun sebelumnya. Perkembangan kondisi ini dicurigai berhubungan dengan faktor genetik familial, infeksi, imunologi serta faktor psikologis. Telah dilaporkan pasien laki-laki 49 tahun dengan keluhan utama lemah letih dan pucat yang disertai bercak kemerahan pada leher, dada, perut, kedua lengan dan paha. Keluhan juga disertai telinga berdenging dan rasa tidak nyaman di perut kanan atas. Manifestasi klinis muncul setelah pasien mengkonsumsi obat anti tuberkulosis selama dua minggu. Pasien juga memiliki riwayat transfusi darah berulang sejak satu tahun yang lalu. Pada pemeriksaan penunjang ditemukan adanya anemia berat dengan gambaran hemolitik dengan Cold Autoantibody Hemolytic Anemia (CAHA), eosinofilia dengan limfosistosis, hyper lgE, hepatosplenomegali akibat hepatitis autoimun, sensorineural hearing loss, serta erupsi kulit eksantema makulopapular. Setelah dilakukan penghentian obat anti tuberkulosis selama lebih dari dua minggu, disertai pemberian imunosupresan, tampak perbaikan yang signifikan pada manifestasi kulit dan hematologi. Pasien dilakukan tes provokasi untuk menentukan obat yang menjadi penyebab erupsi obat alergi.
\end{abstract}

Kata kunci: hyper lgE, obat anti tuberculosis, multiple autoimmune syndrome

\section{Abstract}

Multiple Autoimmune Syndrome (MAS) is a coexistence of three or more autoimmune diseases. The incidence of MAS tends to be high in patients with a history of previous autoimmune diseases. The development of this condition is suspected to be related to familial genetic factors, infections, immunology and psychological factors. It had been reported that a middle age male patients with the main complaint of weakness, fatigue and pale accompanied by reddish spots on the neck, chest, abdomen, arms and thighs. Complaints were also accompanied by ringing in the ears and discomfort in the right upper abdomen. Clinical manifestations appeared after the patient has taken antituberculosis drugs for two weeks. The patient also had a history of repeated blood transfusions since one year ago. On investigations found severe anemia with hemolytic features with cold autoantibodies hemolytic anemia (CAHA), eosinophilia with lymphocystosis, increased serum immunoglobulin E, hepatosplenomegaly caused by autoimmune hepatitis, sensorineural hearing loss, and maculopapular exanthema skin eruption. After stopping the anti tuberculosis drug for more than two weeks, accompanied by immunosuppressant administration, a significant improvement in skin manifestations and hematology was seen. The patient was given a provocation test to determine which drug is causing an allergic drug eruption.

Keywords: anti tuberculosis drug, hyper lgE, multiple autoimmune syndrome

Affiliasi penulis : 1. RSUP Dr. M. Djamil Padang 2. Bagian IImu Penyakit Dalam, Fakultas Kedokteran, Universitas Andalas, Padang, Indonesia / RSUP Dr. M. Djamil Padang

Korespondensi: Fandi Triansyah, Email: ianfandi@yahoo.com Telp: $+6285274373566$

\section{PENDAHULUAN}

Multiple Autoimmune Syndrome

(MAS) merupakan kondisi terjadinya koeksistensi 3 atau lebih penyakit autoimun. Terminologi ini pertama kali diperkenalkan oleh Humbert pada 1988. Penyakit 
autoimun adalah kondisi yang diinisiasi oleh hilangnya toleransi imunologik terhadap self-antigens dan menyebabkan terjadinya kelompok penyakit yang timbul akibat gangguan dari sistem imun baik spesifik pada organ tertentu maupun mempengaruhi tubuh secara sistematis. ${ }^{1}$

Penyakit autoimun terjadi pada sekitar 5\% populasi penduduk dunia. Secara umum kejadian penyakit autoimun lebih tinggi pada wanita dibanding pria. Dengan adanya riwayat penyakit autoimun sebelumnya, terjadi peningkatan kejadian penyakit autoimun lainnya. Pada MAS adanya penyakit kulit autoimun memegang peranan cukup penting. Insidensi dari MAS sendiri jarang, bahkan kejadian 5 koeksistensi penyakit autoimun adalah sangat langka. Faktor familial genetik, infeksi, imunologi dan psikis telah dianggap berperan dalam berkembangnya $\mathrm{MAS}^{2}$

\section{Etiologi}

Adanya faktor pencetus pada individu yang rentan dipercaya mendasari patogenesis disregulasi imun pada individu yang menderita penyakit autoimun. Sebagai contoh adanya infeksi sitomegalovirus dapat memicu terbentuknya autoantibodi multipel. Autoantibodi tertentu ditemukan pada kondisi yang mempengaruhi berbagai organ. Sehingga pasien dengan penyakit autoimun sebelumnya cenderung untuk mengalami kondisi autoimun lainnya. Diperkirakan sekitar $25 \%$ pasien dengan penyakit autoimun memiliki kecenderungan perkembangan penyakit autoimun lainnya. ${ }^{3}$

Fenomena autoimun terutama menonjol pada inflammatory bowel disease, dimana kolitis ulseratif menunjukkan insidensi tinggi sehubungan adanya penyakit terkait autoimun lainnya. Seperti hipotiroidisme, primary sclerosing cholangitis, vitiligo dan alopecia areata. ${ }^{4}$

\section{Manifestasi Klinis}

MAS dibagi menjadi tiga kelompok besar yang dihubungkan dengan prevalensi kejadian penyakit autoimun terkait lainnya. Klasifikasi ini dapat sangat menolong dalam mengidentifikasi adanya koeksistensi kondisi autoimun yang terjadi. Klasifikasi ini memberikan dasar dalam melakukan analisis patofisiologi dan mekanisme autoimunitas yang terjadi. 5

Tabel 1. Klasifikasi multiple autoimmune syndrome ${ }^{4}$

\begin{tabular}{lll}
\hline \multicolumn{1}{c}{ MAS tipe 1 } & \multicolumn{1}{c}{ MAS tipe 2 } & \multicolumn{1}{c}{ MAS tipe 3 } \\
\hline Timoma & Rheumatoid & Autoimmune thyroid \\
Miastenia Gravis & arthritis & disease \\
Poliomiositis & Sjogren syndrome & Myasthenia \\
Giant cell & Pemphigus & Thymoma \\
myocarditis & vulgaris & Sjogren syndrome \\
Pemphigus vulgaris & Primary biliary & Idiopathic \\
Bullous pemphigoid & cirrhosis & thrombocytopenic \\
& Scleroderma & purpura \\
& Autoimmune & Insulin-dependent \\
& thyroid disease & diabetes \\
& & Autoimmune \\
& & hemolytic anemia \\
& & Systemic lupus \\
& & erythematosus \\
& & Dermatitis \\
& & herpetiformis \\
& &
\end{tabular}

\section{Diagnosis}

Penegakan diagnosis MAS diawali dengan adanya riwayat penyakit autoimun sebelumnya pada anamnesis. Kriteria diagnosis sesuai dengan definisi yaitu ditemukannya koeksistensi dari minimal 3 penyakit autoimun secara bersamaan. Diagnosis setiap penyakit autoimun sesuai dengan kriteria penegakan diagnostik masing-masing. Diduga bahwa HLA-B8, DR3 atau DR5 merupakan faktor yang berperan penting terutama pada MAS tipe $3 .{ }^{5}$

\section{KASUS}

Seoranh laki-laki berusia 49 tahun datang ke IGD RSUP Dr. M. Djamil Padang dengan keluhan utama lemah letih yang meningkat sejak 1 minggu sebelum masuk rumah sakit. Awalnya pasien mengeluhkan lemah letih sejak 1 bulan yang lalu. Keluhan lemah letih sebenarnya sudah berulang dari 1 tahun yang lalu, Pasien merasa mudah lelah saat melakukan aktivitas sehari-hari. Pucat disadari pasien sejak 2 minggu yang lalu diikuti dengan timbulnya bercak merah disertai sisik kasar terasa gatal di leher, dada, perut, kedua lengan dan paha. Keluhan kulit muncul setelah pasien mengkonsumsi obat antituberkulosis 1 bulan yang lalu. 
Pasien juga mengeluhkan adanya telinga berdenging sejak 2 minggu yang lalu yang bersifat hilang timbul, terutama saat mengkonsumsi obat antituberkulosis. Selain itu pasien juga mengeluhkan rasa tidak nyaman pada perut bagian kanan atas sejak 1 minggu yang lalu.

Pasien bekerja sebagai seorang karyawan swasta. Pasien tinggal di rumah permanen bersama istri dan 3 orang anaknya dengan ventilasi yang baik dan pencahayaan cukup. Riwayat konsumsi alkohol, penggunaan jarum suntik dan tato tidak ada. Riwayat kontak dengan penderita batuk-batuk lama tidak ada.

Pasien didiagnosis menderita tuberkulosis paru 1 bulan yang lalu dan mendapatkan obat isoniazid $1 \times 300 \mathrm{mg}$, rifampisin $1 \times 450 \mathrm{mg}$, etambutil $1 \times 750 \mathrm{mg}$ dan pirazinamid $1 \times 1000 \mathrm{mg}$ selama 2 minggu. Pasien pernah dirawat tiga kali dengan keluhan lemah dan pucat sejak 1 tahun yang lalu dan mendapat transfusi darah 9 kali.

Pada saat datang ke IGD didapatkan pasien sadar penuh, dengan tekanan darah 130/70 $\mathrm{mmHg}$, frekuensi nafas $18 \mathrm{x} /$ menit, frekuensi nadi $98 \mathrm{x} /$ menit dan suhu tubuh $37^{\circ} \mathrm{C}$. Pada pemeriksaan fisik didapatkan konjungtiva anemis dan hepatosplenomegali. Pada kulit ditermukan makula dan plakat eritema dengan skuama putih di wajah, leher, perut, kedua lengan, dan paha.

Pemeriksaan penunjang menunjukkan $\mathrm{Hb} 5,4$ $\mathrm{gr} / \mathrm{dl}$, leukosit $7.480 / \mathrm{mm}^{3}$ dengan hitung jenis 0/11/5/23/50/11, trombosit $269.000 / \mathrm{mm}^{3}$, retikulosit $6.6 \%$, direct comb's test +3 dan cold antibody positif pada skrining antibodi. Pada gambaran darah tepi didapatkan eritrosit anisositosis normokrom dengan polikromasi, eosinofilia dan limfositosis. Pada pemeriksaan kimia klinik didapatkan SGOT 175 u/l, SGPT $96 \mathrm{u} / \mathrm{l}$, bilirubin indirect $0,4 \mathrm{mg} / \mathrm{dl}$ dan bilirubin direct 0,8 mg/dl, LDH $2960 \mathrm{u} / \mathrm{l}$ serta kadar lgE total $1987 \mathrm{iu} / \mathrm{mL}$.

Pasien telah dilakukan pemeriksaan hepatitis marker berupa $\mathrm{HbSAg}$ non reaktif, anti HCV non reaktif dan IgM anti HAV negatif. Pada pemeriksaan USG hati didapati kesan hepatosplenomegali dan kista subsplenik-suprarenal sinistra. Pasien dikonsultasikan ke bagian THT dengan kesan adanya sensosineural hearing loss bilateral akibat ototoksisitas obat antituberkulosis.

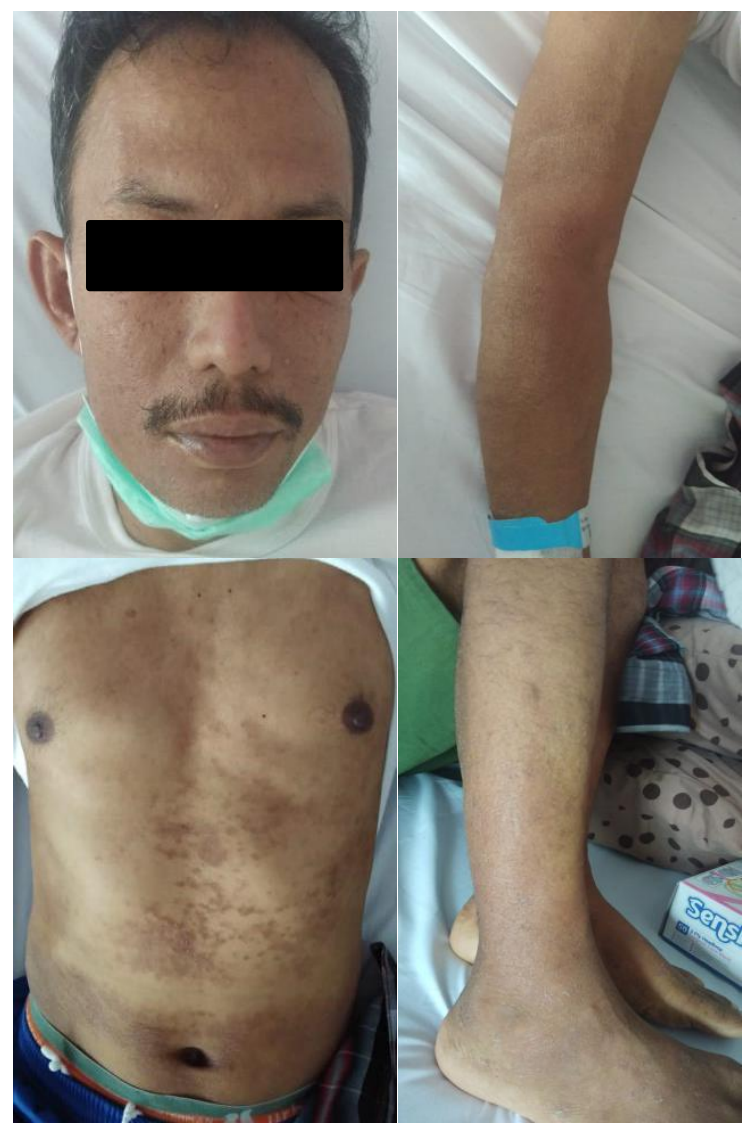

Gambar 1. Lesi kulit berupa makula dan plakat eritema pada wajah, dada, perut, lengan dan tungkai

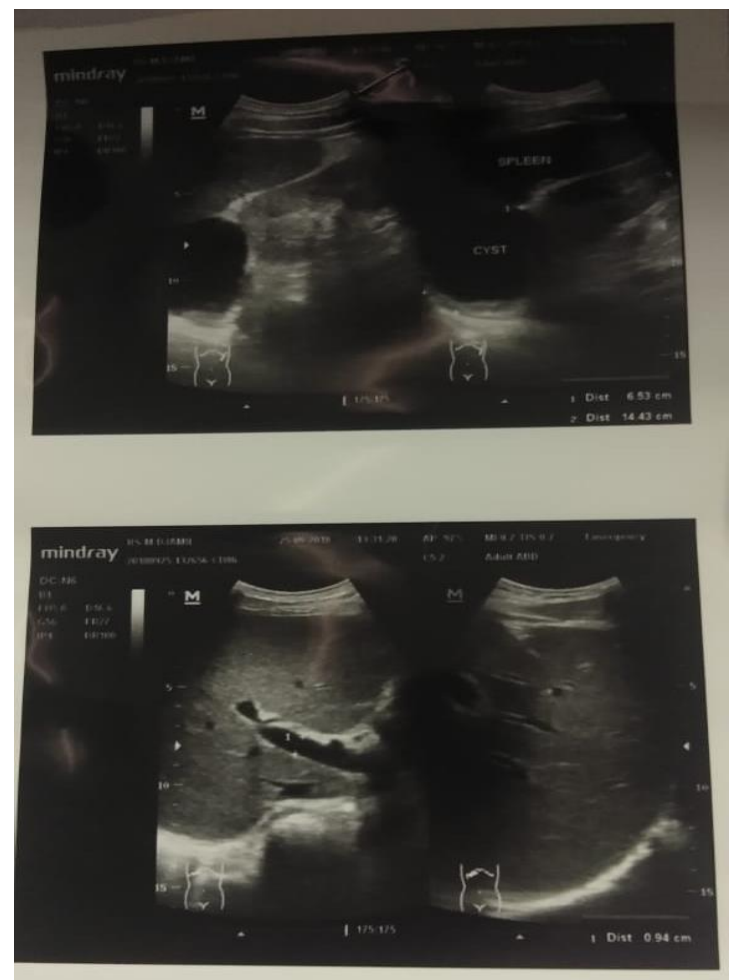

Gambar 2. USG Abdomen dengan gambaran hepatomegali, splenomegali dan kista subspleenik 
Pasien ditatalaksana dengan menghentikan pemberian antituberkulosis, transfusi washed red cell, pemberian kortikosteroid dosis imunosupresan dan terapi simtomatik lainnya. Pada follow up selama perawatan, pasien mengalami perbaikan baik secara klinis dan laboratoris.

\section{PEMBAHASAN}

Telah dirawat seorang laki-laki berusia 49 tahun dengan diagnosis akhir: Multipel Autoimmune Syndrome (CAHA, Hyper-IgE dan Autoimmune Hepatitis) dan Erupsi obat alergi akibat pengobatan OAT kategori 1.

Multiple Autoimmune Syndrome (MAS) pada pasien ini ditegakkan berdasarkan dari anamnesis adanya keluhan anemia berupa pucat dan lemah letih berulang, bercak - bercak merah disertai rasa gatal pada wajah, badan, kedua lengan, dan tungkai sejak 2 minggu yang lalu, dimana awalnya bercak kemerahan berukuran kecil, namun semakin meluas. Rasa tidak nyaman di perut kanan atas dirasakan sejak 2 minggu yang lalu, disertai keluhan telinga berdenging. Pasien mendapat terapi OAT selama 2 minggu sebelumnya.

Hasil pemeriksaan fisik ditemukan adanya konjungtiva anemis, hepatosplenomegali, ruam berupa makula dan plakat eritema pada wajah, lengan, tungkai dan badan. Pemeriksaan laboratorium dijumpai adanya peningkatan anemia berat, retikulositosis, DCT dan cold autoantibody yang positif, eosinophilia dengan Hyper-lgE, limfositosis, peningkatan SGOT, SGPT, bilirubin, LDH. Dari pemeriksaan USG abdomen ditemukan hepatosplenomegali.

Berdasarkan data diatas, pasien memenuh kriteria diagnosis MAS yaitu koeksistensi 3 penyakit autoimun dan berdasarkan klasifikasinya dikelompokkan pada MAS tipe 3 yang meliputi berbagai penyakit kulit, tiroid, metabolik dan hematologik autoimun. ${ }^{6}$ Pada laporan kasus ini, pasien mengalami CAHA. Kejadian CAHA pada MAS adalah sangat jarang. Cold antibody merupakan gambaran AIHA yang jarang, terutama pada laki-laki. Prevalensi CAHA hanya mencapai $7-15 \%$ dari AIHA dan presentasi wanita lebih banyak daripada pria. ${ }^{7}$
Terapi CAHA pada pasien ini adalah dengan metilprednisolon $0,8 \mathrm{mg} / \mathrm{kg}$ bb dibagi dalam 3 dosis. Pasien dengan hemolisis ringan, terapi inisial adalah glukokortikoid. ${ }^{8}$ Kortikosteroid diteruskan sampai nilai hemoglobin meningkat sampai nilai normal, dan kemudian di tappering secara cepat sampai $20 \mathrm{mg}$ per hari, kemudian diturunkan perlahan dalam beberapa bulan. $^{9}$

Pemicu MAS pada pasien ini diduga adalah obat antituberkulosis yang dikonsumsi pasien sehubungan tatalaksana tuberkulosis selama 2 minggu dan mengakibatkan terjadinya erupsi obat alergi. ${ }^{10}$ Penyakit penyerta dan adanya riwayat alergi juga dapat menjadi salah satu faktor risiko terjadinya erupsi obat alergi. ${ }^{11}$ Hasil penelitian deskriptif yang dilakukan di Iran pada tahun 2014, dimana antikonvulsi (51,8\%) menjadi penyebab erupsi obat yang paling banyak ditemukan, kemudian antibiotik $(33,7 \%)$ dan OAINS (5,7\%). ${ }^{12}$

Pada pasien ditemukan erupsi alergi obat tipe makulopapular, dimana 3 bentuk erupsi tersering yang ditemukan adalah makulopapular (32,39\%), FDE $(20,13 \%)$ dan urtikaria $(17,49 \%) .{ }^{13}$ Tata laksana erupsi obat alergi yang utama adalah identifikasi obat penyebab dan menghentikan penggunaannya. Terapi erupsi alergi obat pada pasien ini dengan menggunakan kortikosteroid topikal. ${ }^{14}$

Didapatkan kadar IgE serum total yang tinggi yaitu $1987 \mathrm{IU} / \mathrm{ml}$. Rentang kadar IgE total normal adalah 2-373 IU/ml pada manusia dewasa. ${ }^{15}$ Pasien belum dikategorikan kepada suatu Hyper $\lg \mathrm{E}$ syndrome karena kadar IgE serum tidak melebihi $>2000$ IU/ml dan tanpa adanya infeksi kulit dan paru yang rekuren. ${ }^{16}$

Hepatitis autoimun pada pasien ini ditegakkan berdasarkan skoring dari International Autoimmune Hepatitis Group. Tanpa dilakukan pemeriksaan Smooth Muscle Antibody (SMA) dan biopsi hati, didapatkan skor 10, yang berarti probable untuk hepatitis autoimun. ${ }^{17}$ Probable hepatitis autoimun pada pasien ini tidak diberikan terapi khusus karena regimen steroid sudah diberikan untuk menatalaksana AlHA. Follow-up fungsi hati dilakukan untuk menilai respon terapi pada pasien ini. ${ }^{18}$ 
Pada pasien ditemukan adanya kista pada daerah subsplenik-suprarenal pada pemeriksaan USG abdomen. Untuk kasus ini diperlukan pemeriksaan lebih lanjut berupa CT-scan abdomen untuk menentukan secara pasti letak dan ukuran kista tersebut. ${ }^{19}$

Sensorineural hearing loss (SNHL) pada pasien ini ditegakkan dengan audiometri. Kecurigaan awal ini terjadi akibat efek samping obat anti tuberkulosis. Kecurigaan lain penyebab SNHL adalah kondisi autoimun sistemik AlHA. Menurut Mijovic (2013) penyakit autoimun juga menjadi salah satu penyebab dari SNHL. Pemberian steroid memberikan perbaikan klinis pada pasien dengan SNHL autoimun. ${ }^{20}$

\section{SIMPULAN}

Adanya 1 penyakit autoimun harus sudah menjadi kewaspadaan terjadinya penyakit autoimun lainnya secara bersamaan.

Diagnosis MAS harus dipikirkan pada pasien yang telah dikenal menderita 1 penyakit autoimun mengingat $25 \%$ kasus akan berkembang menjadi MAS, begitu juga halnya pada individu tanpa penyakit autoimun namun memiliki riwayat keluarga menderita penyakit autoimun

\section{DAFTAR PUSTAKA}

1. Cojocaru M, Cojocaru IM, Silosi I. Multiple autoimmune syndrome. Medica Journal of Clinical Medicine. 2010;5(2):132-4

2. Wieloz E, Majdan M, Zychowska I. Coexistence of five autoimmune disease: diagnostic and therapeutic difficulties. Rheumatol Int. 2008; 28(9): 919-23.

3. Sloka S. Observation on recent studies showing increased co-occurrence of autoimmune diseases. Journal of Autoimmunity. 2002;18: 251-7

4. Topal F, Senel E, Akbulut S, Topal F, Dolek Y. A new combination of multiple autoimmune syndrome? Coexistence of vitiligo, autoimmune thyroid disease and ulcerative colitis. Dermatology Reports. 2011;3(19): 43-4

5. Tirado-Sanchez A, Montes-de-Oca G. Coexistence of bullous pemphigoid, vitiligo and thyroid disease:

\section{a multiple autoimmune syndrome? Dermatol Online J. 2005;11: 20-2}

6. Sereshki MM, Almasi S, Behnam B, Semnani F. Autoimmune hemolytic anemia and multiple autoimmune syndrome. European Journal of Case Reports in Internal Medicine. 2019;6:1-3

7. Rojas-Villarraga A, Amaya-Amaya J, Rodriguez AR, Mantilla RD, Anaya JM. Introducing polyautoimmunity: secondary autoimmune disease no longer exist. Autoimmune Dis. 2012:1-9

8. Berentsen S, Roth A, Randen U, Jilma B, Tjonnfjord GE. Cold agglutinin disease: current challenges and future prospects. Journnal of Blood Medicine. 2019;10: 93-103.

9. Barcellini W. New insight in the pathogenesis of autoimmune hemolytic anemia. Tranfus Med Hemother. 2015;42 (5): 287-93.

10. Patel TK, ThakkarSH, Sharma D. Cutaneus adverse drug reaction in indian population: a systemic review. Indian Dermatol Online J. 2014;5(2):1-9

11. Michael OS, Sogaolu OM, Fehintola FA, Ige OM, Falade CO. Adverse events to first line antituberculosis drugs in patients co-infected with HIV and tuberculosis. Ann Ib Postgrad Med. 2016; 14(1): $21-9$

12. Mokhtari F, Nikyar Z, Naeni BA, Esfahani AA, Rahmani S. Adverse cutaneous drug reactions: eight year assesmentin hospital patients. J Res Med Sci. 201;19(8):720-5.

13. Ardern-Jones MR, Friedmann PS. Skin manifestations of drug allergy. Br J Clin Pharmacol. 2011; 71(5): 672-83.

14. Warrington R, Silviu-Dan F, Wong T. Drug allergy. Allergy Asthma Clin Immunol. 2018;14(2):130-9.

15. Shoormasti RS, Pourpak Z, Eshraghian MR, Ashtiani MT, Jamali M, Ziedi M. The study of total $\lg \mathrm{E}$ reference range in healthy adults in Tehran, Iran. Iran J Public Health. 2010; 39(3): 32-6.

16. Freeman FA, Holland SM. The hyper $\lg E$ syndromes. Immunol Allergy Clin North Am. 2008; 28 (2): $277-8$.

17. Gill S. Autoimmune hepatitis: clinical overview and pathological finding. North American Journal of Medicine and Science. 2018.11(1); 6-10. 
18. Teufel A, Weinmann A, Kahaly GJ. Concurrent autoimmune in patients with autoimmune hepatitis. J Clon Gastroenterol. 2010;1: 1-4

19. Golmohammadzeh H, Maddah G, Hojjati YS, Abdollahi A, Shabahang H. Splenic cysts: analysis of 16 cases. Caspian J Intern Med. 2016; 7(3): 217-21.

20. Mijovic T, Zeitouni A, Colmegna I. Autoimmune sensorineural hearing loss: the otologyrheumatology interface. Rheumatology Oxford. 2013; 52(5): 780-9. 